\title{
Is Mild Cognitive Impairment a Valid Target of Therapy
}

\author{
Kenneth Rockwood, Howard Chertkow, Howard H. Feldman
}

\begin{abstract}
The status of Mild Cognitive Impairment (MCI) as a valid construct is controversial. The term encompasses people with heterogeneous clinical profiles, and invites sub-classifications that still require validation. Still, much evidence suggests that, properly selected, many people with MCI - especially Amnestic MCI - are at a high risk of dementia. This paper considers the validity of the construct of MCI as a high-risk state for progression and a target for treatment. We conclude that the status of MCI as an entity remains controversial. On the one hand, it can be argued that the careful section of cases at high risk of developing dementia means that it is a valid target, with the goal being the prevention of dementia. Advocates of this view see a linear progression that they are trying to arrest, but studies have yet to show that this can be done. On the other hand, it can be argued that the patients who progressed did not develop dementia: they actually had a very early form of it. By this view, people without the progressive form will be needlessly exposed to antidementia drugs, and the others should be treated anyway. Why some people progress and others do not is not clear, but the variable rates of progression - between clinic-based and population-based samples and between very similar clinical trials with slightly different inclusion criteria - suggests that MCI is a heterogeneous entity. The phenomenon of slowing or non-progression itself should be investigated, and such investigations likely should extend to people now classified as having mild dementia.
\end{abstract}

RÉSUMÉ: Le déficit cognitif léger est-il une cible de traitement valide? Le statut du déficit cognitif léger (DCL) en tant que concept valide est controversé. Le terme désigne des individus qui ont des profils cliniques hétérogènes et il ouvre la voie à des sous-classifications qui n'ont pas été validées. Cependant il existe beaucoup de données indiquant que, s'ils sont choisis adéquatement, plusieurs individus ayant un DCL, spécialement le DCL amnésique, sont à haut risque de démence. Cet article examine la validité du concept du DCL comme un état à haut risque de progression et une cible de traitement. Nous concluons que le statut du DCL comme entité demeure controversé. D'une part, on peut considérer qu'une sélection précise des cas à haut risque de développer une démence indique qu'il s'agit d'une cible valide, le but étant la prévention de la démence. Ceux qui défendent cette position considèrent qu'il s'agit d'une progression linéaire qu'ils veulent tenter d'arrêter. Cependant les études n'ont pas démontré qu'il est possible de le faire jusqu'à maintenant. D'autre part, on peut considérer que les patients qui ont progressé n'ont pas développé une démence : ils avaient en fait une forme très précoce de démence. Si on adopte ce point de vue, les individus qui n'ont pas la forme progressive seront exposés inutilement aux médicaments anti-démence et les autres devraient être traités de toute façon. On ne sait pas pourquoi le déficit cognitif progresse chez certains individus et pas chez d'autres, mais le taux variable de progression - entre des échantillons recrutés en clinique et des échantillons recrutés dans la population, et entre des essais cliniques très similaires ayant des critères d'inclusion légèrement différents - suggère que le DCL est une entité hétérogène. Le phénomène de la progression lente ou de l'absence de progression devrait faire l'objet d'études et ces études devraient inclure des individus qu'on classifie actuellement comme ayant une démence légère.

Can. J. Neurol. Sci. 2007; 34: Suppl. 1 - S90-96

The status of Mild Cognitive Impairment (MCI) as a therapeutic target for regulatory approval is unclear. On the one hand, many expert physicians feel confident that people who present to memory clinics with memory problems, who have objective data, reviewed clinically, that they are neither normal nor demented can be diagnosed with MCI, and found to be at an increased risk of dementia. ${ }^{1,2}$ For these physicians, the real question - and they see it as a pressing one, of both clinical and public policy importance - is whether this increased risk of progression can be lessened. Others are less sure about each of these points. They question whether MCI is a valid entity, noting that the outcomes of MCI depend greatly on where it is detected, that the results of objective tests are inconsistent within ${ }^{3,4}$ and across studies (i.e. inconsistent in their interpretation, cut-points, correlations and outcomes). ${ }^{5-7}$ This paper considers the question of whether MCI is a well enough established entity that it can be a valid target of therapy within a regulatory context.

From the Department of Medicine (Geriatric Medicine \& Neurology) (KR), Dalhousie University, Halifax, NS; Department of Medicine (Neurology) (HC), McGill

University, Montreal, QC; Department of Medicine (Neurology) (HHF), University of British Columbia, Vancouver, BC, Canada.

RECEIVED OCTOBER 31, 2005. ACCEPTED IN FINAL FORM MAY 29, 2006.

Reprint requests to: Kenneth Rockwood, Centre for Health Care of the Elderly, 14215955 Veterans' Memorial Lane, Halifax, Nova Scotia, B3H 2E1, Canada. 


\section{Validation of the construct of Mild Cognitive IMPAIRMENT}

The validity of a construct can be evaluated in several ways, but a three-part approach distinguishes between content, construct and criterion validity. ${ }^{8}$ Content validity refers to whether an idea is valid on its face. Although at least one careful study, which employed neuropathological comparison, has called it into question, ${ }^{9}$ both broad camps (of advocates and skeptics) agree that many patients with dementia pass through a transitional stage. Still, there is considerable nuance, even in areas of apparent agreement. For example, the advocates of the MCI as high-risk state now recognize subgroups ${ }^{10}$ - an amnestic MCI type which progresses to dementia, and other types (e.g. frontotemporal $\mathrm{MCI}^{11}$ ) that progress to other dementias. In this way, some sense can be made of the considerable heterogeneity that is noted in people with MCI. ${ }^{12-16}$ Clearly, content validity is a weak form of validation, but can be a useful starting point. Here it illustrates a central feature of MCI as now constituted, which is its heterogeneity. It is the resolution of heterogeneity which will be important to how MCI is viewed as a target for therapy.

The persistence of heterogeneity of who is included in various MCI definitions, and what outcomes they experience is at the heart of the MCI controversy, but variable outcomes are not unique to MCI. People with MCI come from a larger pool of people who have cognitive states that, while impaired, do not meet criteria for dementia. For example, the alcohol amnestic syndrome, post-stroke cognitive impairment, congenital cognitive abnormalities, chronic schizophrenia, depression, postinfectious syndromes and traumatic brain injury were each designated as belonging to the group "Cognitive Impairment, No Dementia" (CIND). The CIND group was the single largest entity in the population, according to the Canadian Study of Health and Aging, ${ }^{17}$ and people with many CIND syndromes showed improvement over five years of follow-up. ${ }^{18}$

The setting of MCI in a wider context of CIND is key. The various sets of criteria can be read as a progressive refinement from the most heterogenous category of CIND to a purer 'AMCI' as confounders (alcohol amnestic syndrome, depression, etc.) are eliminated. [Table] From a construct standpoint, there are two problems - what is the nature of what is left over? Is it AMCI or very early Alzheimer's disease? In addition, what is the nature of the conditions that have been excluded? Are they actually confounders, or are they - as might be argued about depression that presents chiefly with cognitive features variants of an underlying process such as Alzheimer's disease?

Much of the evidence for and against the validity of MCI comes from studies of construct validity, in which MCI is evaluated in its correlation with standard measures. A host of studies point to patients with MCI having scores on a variety of tests that are "in between" patients with no cognitive impairment and those with dementia. ${ }^{19-24}$ Some of this is inevitable from the way that MCI is defined. In consequence, it is important to understand the extent to which the memory impairment (in the case of amnestic MCI) correlates with impairment in other domains. This is important because if patients with AMCI have scores "in between" NCI and dementia in memory, but not in other cognitive domains, then it would be easy to accept that AMCI is an isolated memory problem that might herald subsequent dementia. But the common observation that AMCI patients also have "in between' scores on language, attention and concentration, and function can further be taken as evidence that these patients have very mild dementia. The reasoning is that they have global cognitive impairment (memory and at least one other domain) likely with some functional impairment, which thereby would meet the definition of dementia. In short, one important objection to MCI is that it really is early Alzheimer's disease. ${ }^{7}$ The counter-argument from clinicians hinges on two points. First, the definition of dementia stresses that deficits must be "significant", and the "in-between" deficits do not meet this clinically crucial but conceptually ephemeral level of impairment. Secondly, in practice, clinicians must hesitate in concluding or communicating that patients have what is usually an untreatable condition (i.e., dementia), when that individual may be reclassified within three years as being normal! By its very nature MCI in most settings is heterogeneous ${ }^{12-14}$ and any MCI cohort contains individuals who will not progress to dementia ${ }^{16,19}$ and therefore it would be wrong to tell patients that MCI is really just early Alzheimer's Disease. How to distinguish clinically between people who will progress (and thus are legitimate targets of therapy) and those who will not is not yet established.

For people who subscribe to the view that what we really need is better diagnosis of very early dementia, then how might investigations proceed? Some feel that the state could be quickly clarified by better testing - for example, by better neuropsychological batteries, ${ }^{19,25}$ and specifically, better tests of executive function ${ }^{26}$ or of neuroimaging, ${ }^{27}$ making the diagnosis less dependent on clinical judgment. Others, however, are less persuaded that more "objective" testing (either neuropsychological $^{3}$ or neuroimaging ${ }^{28}$ ) would substantially improve diagnosis. There is also disagreement about the same data. For example, even amongst people who meet all of the MCI criteria, the time for progression to dementia varies by many years between patients. Mild Cognitive Impairment advocates see this as confirming the high risk state, making it distinct from early dementia. Mild Cognitive Impairment skeptics call it unacceptable heterogeneity, likely reflecting very early dementia. On the other hand, proponents of (A)MCI as a high risk state might argue that this is a misuse of the term dementia - akin to saying that someone with a rectal temperature of 37.6 (in a setting where infection is suspected) has very early fever. (This too can be countered by pointing out the need to know not just a single observation, but its course.) In such a circumstance, a question that merits consideration is what to call the earliest clinical expression of Alzheimer's disease.

Rates of progression are of particular importance, because predictive validity is an aspect of criterion validation, which is held as the highest form of validity. In a systematic review of 19 longitudinal studies, Bruscoli and Lovestone ${ }^{29}$ concluded that heterogeneity reflected not just how patients were recruited for MCI studies (on this, there is widespread agreement ${ }^{5,30}$ ) but also how the criteria were employed. Specifically, they noted that more stringent measurement of deficits resulted in better prediction of conversion, raising the possibility that highly specified MCI represents very early dementia. Similar disagreements about interpretation exist in considering biological markers, such as CSF beta-amyloid and tau. For example, of 52 patients with MCI, those with elevated levels of tau had a higher 
Table: MCI criteria used in earlier studies

\begin{tabular}{|c|c|c|c|c|c|c|}
\hline Study Reference & $\begin{array}{l}\text { Complaint } \\
\text { Required? }\end{array}$ & $\begin{array}{l}\text { Other Cog. } \\
\text { deficits }\end{array}$ & $\begin{array}{l}\text { Func. } \\
\text { Deficits } \\
\text { allowed }\end{array}$ & $\begin{array}{l}\text { Indication of } \\
\text { normal } \\
\text { intellectual } \\
\text { functioning }\end{array}$ & Tests & Obj. Cut-offs \\
\hline Petersen et al., $1999^{60}$ & $\mathrm{Y}$ & $\begin{array}{c}\text { Not } \\
\text { indicated }\end{array}$ & $\mathrm{N}$ & $\mathrm{Y}$ & $\begin{array}{l}\text { WAIS-R } \\
\text { WMS-R } \\
\text { Auditory Verbal Learning Test } \\
\text { Wide-Range Achievement Test-III } \\
\text { MMSE } \\
\text { Dementia Rating Scale (DRS) } \\
\text { Free and Cued Selective Reminding Test } \\
\text { Boston Naming Test } \\
\text { Controlled Oral Word Association Test } \\
\text { Category Fluency Procedures }\end{array}$ & $\mathrm{n} / \mathrm{a}$ \\
\hline Morris et al., $2001^{7}$ & $\begin{array}{c}\text { Not } \\
\text { indicated }\end{array}$ & $\mathrm{Y}$ & $\mathrm{Y}$ & Not indicated & CDR & $=0.5$ \\
\hline Bennett et al., 2002 ${ }^{61}$ & $\mathrm{~N}$ & $\mathrm{Y}$ & $\begin{array}{c}\text { Not } \\
\text { indicated }\end{array}$ & Not indicated & Extensive neuropsychological battery & $\begin{array}{l}\text { Population specific cutoff } \\
\text { scores used. }\end{array}$ \\
\hline Darby et al., $2002^{62}$ & $\mathrm{Y}$ & $\mathrm{N}$ & $\mathrm{N}$ & Not indicated & CERAD word list recall & $<6$ \\
\hline Hänninen et al., $2002^{63}$ & $\mathrm{~N}$ & $\mathrm{Y}$ & $\mathrm{N}$ & MMSE $\geq 20$ & $\begin{array}{l}\text { - CDR } \\
\text {-Buschke Selective Reminding Test (total immediate } \\
\text { recall during } 6 \text { trials + delayed recall) } \\
\text {-Visual reproduction Test (WMS) (immediate and } \\
\text { delayed recall) } \\
\text { - Logical Memory Test (WMS) (immediate and } \\
\text { delayed recall) } \\
\text { - Boston Naming Test (abbreviated) } \\
\text { - Verbal Fluency Test } \\
\text { - Trail making Test (A+B) } \\
\text { - MMSE }\end{array}$ & $\begin{array}{l}=0.5 \\
\geq 1.5 \mathrm{SD} \text { below healthy } \\
\text { sub-sample cut-off }\end{array}$ \\
\hline Kabani et al., $2002^{22}$ & $\mathrm{Y}$ & $\mathrm{Y}$ & $\mathrm{N}$ & Not indicated & $\begin{array}{l}\text { CDR } \\
\text { Tests of explicit memory }\end{array}$ & $\begin{array}{l}=0.5 \\
\geq 1 \mathrm{SD} \text { below age adjusted } \\
\text { norms }\end{array}$ \\
\hline Larrieu et al., $2002^{64}$ & $\mathrm{Y}$ & $\mathrm{Y}$ & $\mathrm{Y}$ & $\begin{array}{c}\text { MMSE }<1 \mathrm{SD} \\
\text { from age \& ed. } \\
\text { Adjusted cohort } \\
\text { means } \\
\end{array}$ & Benton Visual Retention test & $\begin{array}{l}\geq 1.5 \text { SD below age } \& \text { ed. } \\
\text { Adjusted means }\end{array}$ \\
\hline Busse et al., $2003^{14}$ & $\begin{array}{l}\text { Examined as } \\
\text { a clinical } \\
\text { variable }\end{array}$ & $\mathrm{Y}$ & $\mathrm{N}$ & Not indicated & Structured Mental Status (SIDAM) & $\begin{array}{l}>1 \text { SD below age } \& \text { ed. } \\
\text { Assoc. norms on sub-tests } \\
\text { of SIDAM }\end{array}$ \\
\hline Fisk et al, $2003^{13}$ & $\begin{array}{l}\text { Examined as } \\
\text { a clinical } \\
\text { variable }\end{array}$ & $\mathrm{N}$ & $\begin{array}{l}\text { Examined } \\
\text { as a clinical } \\
\text { variable }\end{array}$ & $\bar{Y}$ & $\begin{array}{l}\text { Benton Visual Retention test; Buschke Cued recall } \\
\text { test, Digit Span, and auditory verbal learnig test; } \\
\text { WAIS-R Similarities, Comprehension, Digit Symbol, } \\
\text { Block design; Token test; COWA; Animal naming. }\end{array}$ & $\begin{array}{l}\text { No cut-offs set; Dx based } \\
\text { on clinical consensus }\end{array}$ \\
\hline Lambon et al., $2003^{65}$ & $\mathrm{Y}$ & $\mathrm{N}$ & $\mathrm{Y}$ & MMSE $>24$ & $\begin{array}{l}\text { - Logical Memory (immediate) } \\
\text { - DRS (memory) }\end{array}$ & $\geq 1.5$ SD's below norms \\
\hline Lopez et al., $2003^{15}$ & $\begin{array}{l}\text { Necessary } \\
\text { for } \\
\text { 'probable' } \\
\text { MCI, but not } \\
\text { 'possible' } \\
\text { MCI }\end{array}$ & $\mathrm{Y}$ & $\mathrm{Y}$ & Not indicated & $\mathrm{n} / \mathrm{a}$ & $\begin{array}{l}\geq 1.5 \text { SD below a sample of } \\
250 \text { unimpaired subjects }\end{array}$ \\
\hline $\begin{array}{l}\text { Farlow et al., } 2004^{66} \\
\text { (InDDEx study) }\end{array}$ & - & $\mathrm{Y}$ & $\mathrm{Y}$ & Not indicated & $\begin{array}{l}\text { CDR } \\
\text { NYU Paragraph recall } \\
\text { HAM-D } \\
\text { HAM-D item } 1\end{array}$ & $\begin{array}{l}0.5 \\
<9 \\
<13 \\
\leq 1\end{array}$ \\
\hline Feldman et al., $2004^{55}$ & $\mathrm{~N}$ & $\begin{array}{c}\text { Not } \\
\text { indicated }\end{array}$ & $\begin{array}{c}\text { Not } \\
\text { indicated }\end{array}$ & Not indicated & $\begin{array}{l}\text { CDR } \\
\text { NYU paragraph recall }\end{array}$ & $\begin{array}{l}<1 \\
<9\end{array}$ \\
\hline Ganguli et al., $2004^{12}$ & $\mathrm{Y}$ & $\begin{array}{c}\text { Not } \\
\text { indicated }\end{array}$ & $\mathrm{N}$ & MMSE $>24$ & CERAD 10 word list delayed recall & $\begin{array}{l}>1 \text { SD below mean of } \\
\text { cohort }\end{array}$ \\
\hline $\begin{array}{l}\text { Grundman et al., 2004 } \\
\text { (ADCS-MIS study) }\end{array}$ & $\mathrm{Y}$ & $\begin{array}{c}\text { Not } \\
\text { indicated }\end{array}$ & $\mathrm{Y}$ & $\mathrm{MMSE} \geq 24$ & $\begin{array}{l}\text { Logical Memory II } \\
\text { Hamilton Dep. Rating Scale }\end{array}$ & $\begin{array}{l}\leq 8(+16 \text { yrs. ed. }) \\
\leq 4(8 \text { to } 15 \text { yrs. Ed. }) \\
\leq 2(0-7 \text { yrs. Ed. }) \\
>12\end{array}$ \\
\hline Royall et al., $2004^{26}$ & $\begin{array}{c}\text { Not } \\
\text { indicated }\end{array}$ & $\begin{array}{l}\text { Examined } \\
\text { as a clinical } \\
\text { variable }\end{array}$ & $\mathrm{Y}$ & Not indicated & $\begin{array}{l}\text { MMSE } \\
\text { CLOX } 1,2 \text { (clock drawing test) } \\
\text { COWA (verbal fluency) } \\
\text { EXIT } 25 \text { (executive interview) } \\
\text { Trail A + B } \\
\text { CVLT (verbal memory) } \\
\text { DRS: MEM }\end{array}$ & $\begin{array}{l}\geq 1.5 \text { SD below average } \\
\text { score of the sample on } \\
\text { each measure }\end{array}$ \\
\hline Solfrizzi et al., $2004^{66}$ & $\mathrm{~N}$ & $\mathrm{Y}$ & $\mathrm{Y}$ & $\begin{array}{l}\mathrm{MMSE}<1.5 \mathrm{SD} \\
\text { from age \& ed. } \\
\text { Adjusted means }\end{array}$ & Babcock Story Recall Test & $\begin{array}{l}\text { score in the lowest } 10^{\text {th }} \\
\text { percentile of the cohort. }\end{array}$ \\
\hline DeJager et al., $2005^{68}$ & $\mathrm{~N}$ & $\mathrm{~N}$ & $\mathrm{Y}$ & Not indicated & $\begin{array}{l}\text { - CERAD 10-word list (free and delayed recall) } \\
\text { - Verbal Paired Associates (cued recall test) } \\
\text { - Pattern and spatial recognition from the CANTAB } \\
\text { - CANTAB Paired Associates Learning (6-items) } \\
\text { - The Placing Test (TPT) }\end{array}$ & $\geq 1.5$ SD's below norms \\
\hline Devanand et al., $2005^{69}$ & $\mathrm{Y}$ & $\mathrm{Y}$ & $\mathrm{Y}$ & $\begin{array}{l}\text { MMSE } \geq 22 \\
\text { Or } \\
\text { If Spanish } \\
\text { speaking with } \\
\text { ed }<5 \text { yrs } \\
\text { MMSE } \geq 18\end{array}$ & $\begin{array}{l}\text { MMSE Delayed recall } \\
\text { Or } \\
\text { Selective Reminding Task } \\
\text { Or } \\
\text { WAIS-R performance IQ score }\end{array}$ & $\begin{array}{l}\leq 2 \text { of } 3 \text { items recalled } \\
\geq 1 \mathrm{SD} \text { below norms } \\
\geq 10 \text { points below WAIS- } \\
\mathrm{R} \text { verbal IQ score. } \\
\text { If no deficits on objective } \\
\text { tests, memory complaint }+ \\
\text { informant's confirmation } \\
\text { of decline and functional } \\
\text { decline. }\end{array}$ \\
\hline Geslani et al., $2005^{70}$ & $\mathrm{Y}$ & $\begin{array}{c}\text { Not } \\
\text { indicated }\end{array}$ & $\mathrm{N}$ & $\begin{array}{l}\text { WAIS-R } \\
\text { similarities or } \\
\text { digit symbol } \\
<0.5 \text { SD from } \\
\text { mean } \\
\end{array}$ & CVLT & $\begin{array}{l}\geq 1.5 \text { SD below age } \& \text { sex } \\
\text { adjusted norms }\end{array}$ \\
\hline
\end{tabular}


Table: continued

\begin{tabular}{|c|c|c|c|c|c|c|}
\hline Kumar et al., $2005^{48}$ & $\bar{Y}$ & $\begin{array}{c}\text { Not } \\
\text { indicated }\end{array}$ & $\mathrm{N}$ & MMSE $>25$ & CVLT & $<2$ \\
\hline Nasreddine et al., $2005^{71}$ & $\mathrm{Y}$ & $\mathrm{Y}$ & $\mathrm{Y}$ & $\mathrm{Y}$ & $\begin{array}{l}\text { Rey Auditory Verbal Learning Test } \\
2 \text { subtests of WMS } \\
\text { (Delayed Visual reproduction and logical memory) }\end{array}$ & At least $1 \mathrm{SD}$ below norms \\
\hline Purser et al., $2005^{72}$ & $\mathrm{~N}$ & $\mathrm{Y}$ & $\begin{array}{l}\text { Examined } \\
\text { as clinical } \\
\text { variable }\end{array}$ & SPMSQ $<4$ & 20 item immediate word recall test & $<4$ \\
\hline Visser et al., $2005^{73}$ & $\begin{array}{c}\text { Not } \\
\text { indicated }\end{array}$ & $\mathrm{Y}$ & $\mathrm{Y}$ & Not indicated & $\begin{array}{l}\text { Global Deterioration Scale } \\
\text { Blessed Dementia Rating scale } \\
20 \text { item story recall }\end{array}$ & $\begin{array}{l}3 \\
\geq 0.5 \text { on first } 8 \text { items if } \\
\text { GDS }=2 \\
\text { cut off based on centile } \\
\text { score estimations for LM, } \\
\text { RAVLT, NYU paragraph } \\
\text { recall }\end{array}$ \\
\hline $\begin{array}{l}\text { Gal Int-11 } \\
\text { (as described in Visser et } \\
\text { al., 2005) }{ }^{2}\end{array}$ & $\begin{array}{c}\text { Not } \\
\text { indicated }\end{array}$ & $\mathrm{Y}$ & Y & Not indicated & $\begin{array}{l}\text { CDR } \\
\text { NYU Paragraph recall }\end{array}$ & $\begin{array}{l}0.5 \\
<11\end{array}$ \\
\hline $\begin{array}{l}\text { Ampakine study (as } \\
\text { described in Visser et al., } \\
2005)^{73}\end{array}$ & $\begin{array}{c}\text { Not } \\
\text { indicated }\end{array}$ & $\begin{array}{l}\mathrm{Y} \\
\mathrm{n}\end{array}$ & Y & MMSE $>24$ & $\begin{array}{l}\text { CDR } \\
\text { Logical Memory II } \\
\text { Geriatric Dep. Scale }\end{array}$ & $\begin{array}{l}0.5 \\
\leq 12(+16 \text { yrs. ed. }), \\
\leq 4 \text { ( } 8 \text { to } 15 \text { yrs. Ed. }) \\
\leq 2 \\
(0-7 \text { yrs. Ed. }) \\
>6\end{array}$ \\
\hline $\begin{array}{l}\text { Piracetam } \\
\text { Study (as described in } \\
\text { Visser et al., 2005) }\end{array}$ & $\begin{array}{c}\text { Not } \\
\text { indicated }\end{array}$ & $\mathrm{Y}$ & $\mathrm{Y}$ & Not indicated & $\begin{array}{l}\text { CDR } \\
\text { Logical Memory I } \\
\text { Logical Memory II } \\
\text { HDRS } \\
\end{array}$ & $\begin{array}{l}0.5 \\
<10 \\
\geq 5 \text { pts below LMI } \\
>17\end{array}$ \\
\hline $\begin{array}{l}\text { Rofecoxib } \\
\text { Study (as described in } \\
\text { Visser et al., 2005) } \\
\end{array}$ & $\begin{array}{c}\text { Not } \\
\text { indicated }\end{array}$ & $\mathrm{Y}$ & $\mathrm{Y}$ & MMSE $>23$ & $\begin{array}{l}\text { CDR } \\
\text { RAVLT total learning } \\
\text { HDRS }\end{array}$ & $\begin{array}{l}0.5 \\
<38 \\
<12\end{array}$ \\
\hline Verghese et al., $2006^{74}$ & $\mathrm{Y}$ & $\mathrm{Y}$ & $\mathrm{N}$ & Verbal IQ $>84$ & Blessed test 5 item memory phrase & $\begin{array}{l}\geq 3 \text { errors ( } \geq 1.5 \text { SD below } \\
\text { norms) }\end{array}$ \\
\hline
\end{tabular}

risk of later being diagnosed with $\mathrm{AD} .{ }^{31}$ On the other hand, their baseline tau levels considerably overlapped into the AD range, again raising the question of how appropriate is the concept of "conversion" compared with "reassignment of diagnostic category". Similar results were seen in an earlier smaller study. ${ }^{32}$

\section{Clinical trials in MCI AS A FORM OF PREDICTIVE VALIDITy}

The evaluation of predictive validity is another way in which cholinesterase inhibitor trials might be understood. In essence, the clinical trials can operate, at the level of the concept, as a diagnostic and therapeutic trial often operates at the level of the patient. Initial results of studies with cholinesterase inhibitors have yielded equivocal results. ${ }^{33-36}$ In consequence, it is not yet possible to conclude whether MCI is a form of dementia with a variable treatment response, or whether it is a separable entity for which treatment might or might not be preventive. The MCI studies themselves varied; while they demonstrated a strong relationship between apoE4 and the risk of developing clinically evident dementia, ${ }^{34}$ they varied importantly in the proportions who carried an ApoE4 allele. ${ }^{37}$ as well as the proportion who might, in other contexts, be described as having "very early dementia". 38

In dementia studies, there is a strong tradition of considering criterion validity chiefly in the form of referent validation, with the referent being a so-called "gold standard". The "gold standard" was held to be neuropathology, although the existence of several sets of neuropathological criteria that can yield conflicting results diminishes the luster of this approach somewhat. ${ }^{39,40}$ Importantly, not all studies show a dose response between putative pathogenic factors and $\mathrm{NCI}, \mathrm{MCI}$ and AD. ${ }^{41-43}$ On the other hand, neurocompensatory responses might be more specific, so that static levels might not reflect dynamic changes, ${ }^{44-46}$ making simple correlative studies- even with neuropathology - an inadequate test of validity.

\section{Conclusions}

In general, it seems logical to propose that cholinesterase inhibitors having not been demonstrably effective reflects either that: the MCI concept is valid, but the drugs are ineffective, or; MCI is valid, the drugs are effective, but the outcome measures used to detect treatment effects have been insensitive to clinically important change, or; the MCI concept is not valid enough to select operational criteria which pick out people with demonstrable memory impairment who might respond to treatment with a cholinesterase inhibitor. The present data do not readily allow for these possibilities to be distinguished, but they do show that even small differences in clinical trials enrollment criteria appear to make big differences in the rates of progression, even if attempting to have more rigorous criteria in population studies does not affect progression (or recovery).

An important policy consideration in knowing whether MCI is a valid target of treatment is that, as we have seen, MCI is not the only form of cognitive impairment that falls between normal cognitive function and dementia. In consequence, it is clear that questions about definition - which is central to the current controversies about MCI as a therapeutic target - are essential features and not regulatory niceties. ${ }^{37}$ Definitional nuances also have policy implications in that minor changes in how MCI is defined can result in three-fold differences in prevalence. ${ }^{13,47,48}$ If MCI is to become a treatable "disease" then careful attention needs to be paid to criteria, lest it become a rapidly spreading epidemic! 
We note that MCI is potentially a target of therapy not just for cholinesterase inhibitors. There is now a set of publications which demonstrate a lack of depletion of choline acetyltransferase in MCI, or in mild AD brains, for that matter. ${ }^{44,49,50}$ Unimpressive symptomatic trials of ChEIs would support this view. Additionally, MCI is being evaluated as an entity driven by cerebrovascular disease, suggesting that it might also be a target for vascular risk factor modification. ${ }^{51}$ Other compounds that have been evaluated for use using current MCI criteria include rofecoxib $^{52}$ and Vitamin E. ${ }^{33}$

Many of the controversies about how to conceptualize MCI are amenable to pragmatic research programs, and should motivate better funding for systematic inquiry. Future studies might well make the controversy obsolete. For example, if an anti-amyloid compound that is potentially disease-modifying that might, in fact, prevent dementia - were to be studied, then it might well be studied in people who were genetically at risk, even if they did not have MCI/very early Alzheimer's disease. On the other hand, unless prevention of dementia is completely effective, it might well be that future 'prevented dementia' would look more like MCI (or CIND) than like normal cognitive function.

If many people with MCI actually have early dementia, which increasingly seems likely, ${ }^{53}$ then how to identify this group needs better attention. It is likely that clinically sensible tests of executive function will be of particular value. ${ }^{26}$ It might also be that the comparatively little attention paid to behavioural manifestations has lessened the sensitivity and specificity of the MCI construct. ${ }^{54-56}$ In this regard, an epidemiological and clinical research program that evaluated MCI in relation to depression would be of particular value. ${ }^{57}$ Further specification of the number and types of domains that are affected might also yield greater specificity. ${ }^{58}$ Hypotheses such as these - and the hypothesis that intervention can delay progression in very early dementia - merit specific testing, using both standard tests, and more sensitive measures than those now generally employed. Such a program would require a much more sophisticated evaluation of patients than is now routinely available outside of the academic research setting in Canada. In consequence, it appears that MCI as a high-risk state putatively distinct from very early dementia is best understood as an entity that requires additional research, including at the level of concept validation. ${ }^{59}$ Intervention studies should therefore be undertaken with a view to clarifying the concept, targets of treatment and identification of potential responder groups.

\section{DEClaration}

Kenneth Rockwood is supported by an Investigator Award from the Canadian Institutes of Health Research (CIHR) and the Dalhousie Medical Research Foundation as the Kathryn Allen Weldon Professor of Alzheimer's Research. Howard Chertkow is a "chercheur national" of the FRSQ (Fonds de la Recherche en Santé du Québec).

Kenneth Rockwood, Howard Chertkow and Howard Feldman each receive research support from the CIHR. Dr. Rockwood receives research funding from the Alzheimer Society of Canada. Dr. Chertkow also receives research funding from the FRSQ.

Kenneth Rockwood holds research grants from Janssen Ortho and Merck, and has received speakers fees from Janssen Ortho,
Merck, Novartis and Pfizer. Howard Feldman has received grant funding from Pfizer, Eisai, and Janssen Pharma. These companies are manufacturers of drugs being investigated for the treatment of mild cognitive impairment.

Within the past 2 years Howard H. Feldman has served as a consultant, received grant funding or participated in CME programs sponsored by Astra Zeneca, Pfizer, Eisai, Novartis, Janssen, Servier, Sanofi Synthelabo, Lilly, GlaxoSmithKline, Myriad, Targacept, Forest, Lundbeck and Axonyx.

\section{REFERENCES}

1. Winblad B, Palmer K, Kivipelto M, Jelic V, Fratiglioni L, Wahlund LO, et al. Mild cognitive impairment-beyond controversies, towards a consensus: report of the International Working Group on Mild Cognitive Impairment. J Intern Med. 2004; 256:240-6.

2. Grundman M, Petersen RC, Ferris SH, Thomas RG, Aisen PS, Bennett DA, et al. Mild cognitive impairment can be distinguished from Alzheimer disease and normal aging for clinical trials. Arch Neurol. 2004; 61:59-66.

3. Ingles JL, Fisk JD, Merry HR, Rockwood K. Five-year outcomes for dementia defined solely by neuropsychological test performance. Neuroepidemiology. 2003;22:172-8.

4. MacKnight C, Graham J, Rockwood K. Factors associated with inconsistent diagnosis of dementia between physicians and neuropsychologists. J Am Geriatr Soc. 1999;47:1294-9.

5. Davis H, Rockwood K. Conceptualization of mild cognitive impairment: a review. Int J Geriatr Psychiatry. 2004;19: 313-9.

6. Panza F, D'Introno A, Colacicco AM, Capurso C, Del Parigi A, Caselli RJ, et al. Current epidemiology of mild cognitive impairment and other predementia syndromes. Am J Geriatr Psychiatry. 2005;13:633-44.

7. Morris JC, Storandt M, Miller JP, McKeel DW, Price JL, Rubin EH, et al. Mild cognitive impairment represents early-stage Alzheimer disease. Arch Neurol. 2001;58:397-405.

8. Streiner D, Norman G. Health Measurement Scales: a guide to their development and use. 3rd ed. Oxford: Oxford University Press; 2003.

9. Goldman WP, Price JL, Storandt M, Grant EA, McKeel DW Jr, Rubin $\mathrm{EH}$, et al. Absence of cognitive impairment or decline in preclinical Alzheimer's disease. Neurology. 2001;56:361-7.

10. Petersen RC, Doody R, Kurz A, Mohs RC, Morris JC, Rabins PV, et al. Current concepts in mild cognitive impairment. Arch Neurol. 2001;58:1985-92.

11. de Mendonca A, Ribeiro F, Guerreiro M, Garcia C. Frontotemporal mild cognitive impairment. J Alzheimers Dis. 2004;6:1-9.

12. Ganguli M, Dodge HH, Shen C, DeKosky ST. Mild cognitive impairment, amnestic type: an epidemiologic study. Neurology. 2004;63:115-21.

13. Fisk J, Merry H, Rockwood K. Variations in case definition affect prevalence but not outcomes of mild cognitive impairment. Neurology. 2003;61:1179-84.

14. Busse A, Bischkopf J, Riedel-Heller SG, Angermeyer MC. Subclassifications for mild cognitive impairment: prevalence and predictive validity. Psychol Med. 2003;33:1029-38.

15. Lopez OL, Jagust WJ, DeKosky ST, Becker JT, Fitzpatrick A, Dulberg C, et al. Prevalence and classification of mild cognitive impairment in the Cardiovascular Health Study Cognition Study: part 1. Arch Neurol. 2003;60:1385-9.

16. Wahlund LO, Pihlstrand E, Jonhagen ME. Mild cognitive impairment: experience from a memory clinic. Acta Neurol Scand Suppl. 2003;179:21-4.

17. Graham JE, Rockwood K, Beattie BL, Eastwood R, Gauthier S, Tuokko H, et al. Prevalence and severity of cognitive impairment with and without dementia in an elderly population. Lancet. 1997;349:1793-6.

18. Tuokko H, Frerichs R, Graham J, Rockwood K, Kristjansson B, Fisk $\mathrm{J}$, et al. Five-year follow-up of cognitive impairment with no dementia. Arch Neurol. 2003:60:577-82.

19. Dwolatzky T, Whitehead V, Doniger GM, Simon ES, Schweiger A, Jaffe D, et al. Validity of a novel computerized cognitive battery for mild cognitive impairment. BMC Geriatr. 2003;3:4. 
20. Peng S, Wuu J, Mufson EJ, Fahnestock M. Increased proNGF levels in subjects with mild cognitive impairment and mild Alzheimer disease. J Neuropathol Exp Neurol. 2004;63:641-9.

21. de Leon MJ, DeSanti S, Zinkowski R, Mehta PD, Pratico D, Segal $\mathrm{S}$, et al. MRI and CSF studies in the early diagnosis of Alzheimer's disease. J Intern Med. 2004;256:205-23.

22. Kabani NJ, Sled JG, Chertkow H. Magnetization transfer ratio in mild cognitive impairment and dementia of Alzheimer's type. Neuroimage. 2002;15:604-10.

23. Mandzia J, Black S, Grady C, McAndrews MP, Graham S. Encoding and retrieval in aging and memory loss, a fMRI study. Brain Cogn. 2002;49:225-8.

24. Smith GE, Bohac DL, Waring SC, Kokmen E, Tangalos EG, Ivnik $\mathrm{RJ}$, et al. Apolipoprotein E genotype influences cognitive 'phenotype' in patients with Alzheimer's disease but not in healthy control subjects. Neurology. 1998;50:355-62.

25. Artero S, Tierney MC, Touchon J, Ritchie K. Prediction of transition from cognitive impairment to senile dementia: a prospective, longitudinal study. Acta Psychiatr Scand. 2003;107:390-3.

26. Royall DR, Chiodo LK, Polk MJ. Misclassification is likely in the assessment of mild cognitive impairment. Neuroepidemiology. 2004;23:185-91.

27. Jack CR Jr., Shiung MM, Gunter JL, O'Brien PC, Weigand SD, Knopman DS, et al. Comparison of different MRI brain atrophy rate measures with clinical disease progression in AD. Neurology. 2004 24;62:591-600.

28. DeCarli C, Mungas D, Harvey D, Reed B, Weiner M, Chui H, et al. Memory impairment, but not cerebrovascular disease, predicts progression of MCI to dementia. Neurology. 2004 Jul 27;63: 220-7.

29. Bruscoli M, Lovestone S. Is MCI really just early dementia? A systematic review of conversion studies. Int Psychogeriatr. 2004; 16:129-40.

30. Petersen RC. Challenges of epidemiological studies of mild cognitive impairment. Alzheimer Dis Assoc Disord. 2004;18:1-2.

31. Hampel H, Teipel SJ, Fuchsberger T, Andreasen N, Wiltfang J, Otto $\mathrm{M}$, et al. Value of CSF beta-amyloid1-42 and tau as predictors of Alzheimer's disease in patients with mild cognitive impairment. Mol Psychiatry. 2004;9:705-10.

32. Riemenschneider M, Lautenschlager N, Wagenpfeil S, Diehl J, Drzezga A, Kurz A. Cerebrospinal fluid tau and beta-amyloid 42 proteins identify Alzheimer disease in subjects with mild cognitive impairment. Arch Neurol. 2002;59:1729-34.

33. Salloway S, Ferris S, Kluger A, Goldman R, Griesing T, Kumar D, et al. Efficacy of donepezil in mild cognitive impairment: a randomized placebo-controlled trial. Neurology. 2004;63:651-7.

34. Petersen RC, Thomas RG, Grundman M, Bennett D, Doody R, Ferris $\mathrm{S}$, et al. Vitamin $\mathrm{E}$ and donepezil for the treatment of mild cognitive impairment. N Engl J Med. 2005; 352:2379-88.

35. Johnson and Johnson Pharmaceutical Research and Development. Synopsis. GAL-INT-11. http://www.clinicalstudyresults.org./ documents/company study 96 1.pdf.

36. Johnson and Johnson Pharmaceutical Research and Development. Synopsis. GAL-INT-11. Available from: http://www.clinical studyresults.org./documents/company study 96 2.pdf.

37. Schneider L. Mild cognitive impairment. Am J Geriatr Psychiatry. 2005;13:629-32.

38. Morris JC, Cummings J. Mild cognitive impairment (MCI) represents early-stage Alzheimer's disease. J Alzheimers Dis. 2005; 7:235-9

39. Knopman DS, Parisi JE, Salviati A, Floriach-Robert M, Boeve BF, Ivnik RJ, et al. Neuropathology of cognitively normal elderly. J Neuropathol Exp Neurol. 2003;62:1087-95.

40. Medical Research Council Cognitive Function and Aging Study. Pathological correlates of late-onset dementia in a multicentre, community-based population in England and Wales. Neuropathology Group of the Medical Research Council Cognitive Function and Aging Study (MRC CFAS). Lancet. 2001;357:169-75.

41. Wang DS, Bennett DA, Mufson E, Cochran E, Dickson DW. Decreases in soluble alpha-synuclein in frontal cortex correlate with cognitive decline in the elderly. Neurosci Lett. 2004;359:104-8.
42. Mufson EJ, Ma SY, Dills J, Cochran EJ, Leurgans S, Wuu J, et al. Loss of basal forebrain P75(NTR) immunoreactivity in subjects with mild cognitive impairment and Alzheimer's disease. J Comp Neurol. 2002;443:136-53.

43. Mufson EJ, Chen EY, Cochran EJ, Beckett LA, Bennett DA, Kordower JH. Entorhinal cortex beta-amyloid load in individuals with mild cognitive impairment. Exp Neurol. 1999;158:469-90.

44. DeKosky ST, Ikonomovic MD, Styren SD, Beckett L, Wisniewski S, Bennett DA, et al. Upregulation of choline acetyltransferase activity in hippocampus and frontal cortex of elderly subjects with mild cognitive impairment. Ann Neurol. 2002;51:145-55.

45. Grady CL, McIntosh AR, Beig S, Keightley ML, Burian H, Black SE. Evidence from functional neuroimaging of a compensatory prefrontal network in Alzheimer's disease. J Neurosci. 2003; 23:986-93.

46. Counts SE, Nadeem M, Wuu J, Ginsberg SD, Saragovi HU, Mufson EJ. Reduction of cortical TrkA but not p75(NTR) protein in earlystage Alzheimer's disease. Ann Neurol. 2004;56:520-31.

47. Fisk JD, Rockwood K. Outcomes of incident mild cognitive impairment in relation to case definition. J Neurol Neurosurg Psychiatry. 2005;76:1175-7.

48. Kumar R, Dear KB, Christensen H, Ilschner S, Jorm AF, Meslin C, et al. Prevalence of mild cognitive impairment in 60- to 64-yearold community-dwelling individuals: The personality and total health through life 60+ study. Dement Geriatr Cogn Disord. 2005;19:67-74.

49. Ikonomovic MD, Mufson EJ, Wuu J, Cochran EJ, Bennett DA, DeKosky ST. Cholinergic plasticity in hippocampus of individuals with mild cognitive impairment: correlation with Alzheimer's neuropathology. J Alzheimers Dis. 2003;5:39-48.

50. Gilmor ML, Erickson JD, Varoqui H, Hersh LB, Bennett DA, Cochran EJ, et al. Preservation of nucleus basalis neurons containing choline acetyltransferase and the vesicular acetylcholine transporter in the elderly with mild cognitive impairment and early Alzheimer's disease. J Comp Neurol. 1999;411:693-704.

51. Panza F, D'Introno A, Colacicco AM, Capurso C, Parigi AD, Capurso SA, et al. Cognitive frailty: predementia syndrome and vascular risk factors. Neurobiol Aging. 2006;27:933-40.

52. Thal LJ, Ferris SH, Kirby L, Block GA, Lines CR, Yuen E, et al. A randomized, double-blind study of Rofecoxib in patients with mild cognitive impairment. Neuropsycho-pharmacology. 2005;3:1-12.

53. Morris JC. Mild cognitive impairment is early-stage Alzheimer disease: time to revise diagnostic criteria. Arch Neurol. 2006;63:15-6.

54. Lyketsos CG, Lopez O, Jones B, Fitzpatrick AL, Breitner J, DeKosky S. Prevalence of neuropsychiatric symptoms in dementia and mild cognitive impairment: results from the cardiovascular health study. JAMA. 2002;288:1475-83.

55. Feldman H, Scheltens P, Scarpini E, Hermann N, Mesenbrink P, Mancione L, et al. Behavioral symptoms in mild cognitive impairment. Neurology. 2004;62:1199-201.

56. Ritchie K, Touchon J. Mild cognitive impairment: conceptual basis and current nosological status. Lancet. 2000;355:225-8.

57. Steffens DC, Otey E, Alexopoulos GS, Butters MA, Cuthbert B, Ganguli M, et al. Perspectives on depression, mild cognitive impairment, and cognitive decline. Arch Gen Psychiatry 2006;63:130.

58. Rasquin SM, Lodder J, Visser PJ, Lousberg R, Verhey FR. Predictive accuracy of MCI subtypes for Alzheimer's disease and vascular dementia in subjects with mild cognitive impairment: a 2 year follow up study. Dement Geriatr Cogn Disord. 2005;19:113-9.

59. Whitehouse PJ, Juengst ET. Antiaging medicine and mild cognitive impairment: practice and policy issues for geriatrics. J Am Geriatr Soc. 2005;53:1417-22.

60. Petersen RC, Smith GE, Waring SC, Ivnik RJ, Tangalos EG, Kokmen E. Mild cognitive impairment: clinical characterization and outcome. Arch Neurol. 1999;56:303-8. Erratum in: Arch Neurol. 1999;56:760.

61. Bennett HP, Corbett AJ, Gaden S, Grayson DA, Kril JJ, Broe GA. Subcortical vascular disease and functional decline: a 6-year predictor study. J Am Geriatr Soc. 2002;50:1969-77. 
62. Darby D, Maruff P, Collie A, McStephen M. Mild cognitive impairment can be detected by multiple assessments in a single day. Neurology. 2002;59:1042-6.

63. Hanninen T, Hallikainen M, Tuomainen S, Vanhanen M, Soininen H. Prevalence of mild cognitive impairment: a population-based study in elderly subjects. Acta Neurol Scand. 2002;106:148-54.

64. Larrieu S, Letenneur L, Orgogozo JM, Fabrigoule C, Amieva H, Le $\mathrm{CN}$, et al. Incidence and outcome of mild cognitive impairment in a population-based prospective cohort. Neurology 2002;59:1594-9.

65. Lambon RMA, Patterson K, Graham N, Dawson K, Hodges JR. Homogeneity and heterogeneity in mild cognitive impairment and Alzheimer's disease: a cross-sectional and longitudinal study of 55 cases. Brain. 2003;126(Pt 11):2350-62.

66. Farlow MR, He Y, Tekin S, Xu J, Lane R, Charles HC. Impact of APOE in mild cognitive impairment. Neurology. 2004;63: 1898-901.

67. Solfrizzi V, Panza F, Colacicco AM, D'Introno A, Capurso C, Torres $\mathrm{F}$, et al. Italian longitudinal study on aging working group. Vascular risk factors, incidence of MCI, and rates of progression to dementia. Neurology. 2004;63:1882-91.

68. De Jager C, Blackwell AD, Budge MM, Sahakian BJ. Predicting cognitive decline in healthy older adults. Am J Geriatr Psychiatry. 2005;13:735-40.
69. Devanand DP, Pelton GH, Zamora D, Liu X, Tabert M, Goodkind M, et al. Predictive utility of apolipoprotein E genotype for Alzheimer disease in outpatients with mild cognitive impairment. Arch Neurol. 2005;62:975-80.

70. Geslani DM, Tierney MC, Herrmann N, Szalai JP. Mild cognitive impairment: an operational definition and its conversion rate to Alzheimer's disease. Dement Geriatr Cogn Disord. 2005;19: 383-9.

71. Nasreddine ZS, Phillips NA, Bedirian V, Charbonneau S, Whitehead V, Collin I, et al. The Montreal cognitive assessment, MoCA: a brief screening tool for mild cognitive impairment. J Am Geriatr Soc. 2005;53:695-9.

72. Purser JL, Fillenbaum GG, Pieper CF, Wallace RB. Mild cognitive impairment and 10-year trajectories of disability in the Iowa established populations for epidemiologic studies of the elderly cohort. J Am Geriatr Soc. 2005;53:1966-72.

73. Visser P J, Scheltens P, Verhey FR. Do MCI criteria in drug trials accurately identify subjects with predementia Alzheimer's disease? J Neurol Neurosurg Psychiatry. 2005;76:1348-54.

74. Verghese J, LeValley A, Hall CB, Katz MJ, Ambrose AF, Lipton RB. Epidemiology of gait disorders in community-residing older adults. J Am Geriatr Soc. 2006;54:255-61. 